\title{
Intent and Meaning of Information about Corona Virus on Social Media: Forensic Linguistic Study in the Case of Spreading Hoax
}

\author{
Krisanjaya $^{1, *}$ Erfi Firmansyah $^{1}$ Aulia Rahmawati $^{1}$ \\ ${ }^{1}$ Indonesian Literature Study Program, Faculty of Language and Arts, Universitas Negeri Jakarta. \\ *Corresponding author Author Email: jayakrisan13@gmail.com
}

\begin{abstract}
This research aims to apply semantic theory in analyzing the intent and meaning of information about the Corona Novel Virus or COVID-19 on social media in the case of spreading fake news or hoax. Predicative verbs that are studied include: 1) structure/construction of verbs in social media, 2) behavior of verbs, and (3) the meaning of verbs as predicates in sentences. The morphological processes of verbs studied in the case of spreading fake news are affixation, reduplication, and abbreviation that characterize the crime. The semantic scope of verbs studied in this law includes the use of verbs singly or in sequence, positive or negation, base and derivative, and original or translation/loan word/equivalent.

This qualitative descriptive research was carried out for eight months, namely March-December 2020 with variables of the intent and meaning of information, as well as the morphological processes (affixation, reduplication, and abbreviation) contained in the utterance of criminal cases spreading fake news (hoax) about the Corona Novel Virus or COVID- 19. The data collection techniques carried out were: 1) the data provision stage, 2) the data analysis stage (with the equivalent method and the different method), and 3) the presentation of the results of the analysis of primary data in the form of verbs in speech which became the material for criminal cases of spreading fake news purposive sampling.

This research shows that information on social media and potentially criminal to spread false news about Covid-19 can be classified as: 1) the characteristics of the corona virus, the source of the corona virus, distribution of corona, corona virus barriers, the corona cure, and the condition of the figure. The element of intent that is in what is said on social media and has the potential to be criminalized in spreading fake news about Covid-19 can be described as advise, confirming, and reporting.

Keywords: intent, meaning, social media, spreading hoax.
\end{abstract}

\section{INTRODUCTION}

The development of media using the internet is currently very rapid in Indonesia. The rapid development of technology now has many new social media applications popping up in cyberspace. By relying on devices or gadgets connected to the internet, people can already access several social media sites such as Facebook, Twitter, Line, Wechat, Kakao Talk. These social media sites can be accessed anywhere and anytime as long as they are connected with an internet connection.

Social media is a medium that allows users to socialize and interact with each other, share information and collaborate via the internet. Because it is connected to the internet, social media allows a cosmopolitan society to be formed, even though in an unreal form. Here freedom becomes an element that is often echoed in the heyday of cyberspace. Having an account on various social media is an individual right that must be respected and have freedom of expression. Cyber space is seen as a virtual world that is borderless and lawless as expressed by Lawrence Lessig in Laws of Cyberspace (1998) and John Perry Barlow in the Declaration of Independence of Cyberspace (1996). Cyber crime is all kinds of use of computer networks for criminal purposes and/or high-tech criminals by misusing the convenience of digital technology. [1]

Hate speech is increasing in number online. For Indonesians who are plural, the impact of the spread of hoaxes and hate speech is really worrying. [2] Everything that can be accessed in cyberspace can be both beneficial and misleading. News content in cyberspace ---including communication via social media--- can be classified into true news and fake news. The rise in circulating fake news or hoaxes can have bad consequences for the development of the Indonesian state. Hoaxes can cause debate, and even break the friendship.

Hoax or false information that is spread through online social media is a means used by the public to reason post-truth to expose untruths.[3] Kumar et al. 
[4] conducted an experiment with hoax articles created by hoaxsters on Wikipedia. They hired Amazon Mechanical Turk workers and showed them one hoax and one non-hoax article side-by-side, with the task to identify which one of the two articles was a hoax article without searching for information elsewhere. A total of 320 pairs of hoax and non-hoax articles were created and each pair was shown to 5 different workers. Humans correctly identified the hoax a mere $66 \%$ of times, only marginally higher than the random guessing baseline of $50 \%$.

Indeed, the state in writing has guaranteed freedom of opinion for everyone. Freedom of opinion has its own laws. Article 28 letter E paragraph 3 of the 1945 Constitution. However, the lack of knowledge and the reluctance to find out the truth of news can make the spread of hoaxes very fast. This situation is compounded by the online news format with news which only consists of a few paragraphs, with the presentation tending to be incomplete or given a 'read more' feature.

The freedom of expression in the use of social media does not all contain true news in terms of content. The Ministry of Communication and Informatics released hundreds of findings of false information (hoax) and disinformation related to the Corona Novel Virus or COVID-19. Misinformation regarding the corona virus began to emerge in January 2020. Based on Mafindo's monitoring results, from January to March 3, Mafindo managed to nab 103 topics about corona hoaxes and some of them caused panic in society.[5] As for the end of the fourth week of January to 10 August 2020, 1,028 hoaxes related to COVID-19 have been identified. $^{6}$

A group of people still remained misinformed and uninformed about COVID-19 (its origin, transmission and preventive measures). Public health authorities and other parties concerned about public health education should be more aware of clarifying those misinformation issues, particularly virus transmission and preventive measures. They could use various forms of social media to spread truths to tackle misinformation. Again, even though the public might have been informed several times, education on how to choose accurate information should be intensified. Otherwise, more people will be exposed to a lot of misinformation which can place them at risk of performing wrong protocol and preventive measures. $\left[{ }^{7}\right]$

Linguistics as a distinctive science may contribute to the science of law in terms of interpreting the meaning of words that become cases in police investigations to the stage of prosecution in court. These benefits include linguistic support for the meaning of lying and misleading as a criminal case. In the context of the spread of the Corona Novel Virus or COVID-19 on social media, fake news or hoaxes of criminal offenses can have a disruptive social impact. The causes may vary from political interests, business competition, hatred of a group and even just wanting to seek sensation. In this hoax case lies the contribution of forensic linguistics in legal discovery. Linguistic clarity is needed in order to increase the brightness of a hoax case. This can lead to the decision that will be handed down by the panel of judges is the fairest possible. In addition, legal discovery through semantic identification of verbs can be used as learning material for the community in terms of using Indonesian words carefully. This is where it seems clear that serious efforts are needed to identify, categorize, and justify the semantic meaning of verbs and the morphological processes of Indonesian that shape them to shed light on a case of spreading fake news or hoaxes.

\section{RELEVANT THEORETICAL REVIEWS}

\subsection{Intend and Meaning of Semantics}

In linguistic studies, the concept of intent is in the realm of discourse. The concept of intent is always associated with the concept of semantic presuppositions and pragmatic presuppositions. Presuppositions are what speakers use as a common ground for conversation participants. [8] Presuppositions are the assumptions or inferences implied in certain linguistic expressions. [9]

The meaning itself was seen by several figures as part of the study of meaning. Kridalaksana [10] provides several definitions of the term meaning (meaning, linguistic meaning, sense), namely: (1) the intent of the speaker; (2) the influence of the language unit in understanding the perception or behavior of humans or groups of people; (3) relations, in the sense of equivalence between language and nature outside the language, or between utterances and all the things it indicates; (4) how to use language symbols.

In the study of law, the concept of intent is related to criminal or illegal acts committed by the perpetrator. The purpose or voornemen in an experiment or poging is explained in Article 53 paragraph (1) of the Criminal Code. Various purposes or brands exist in crimes of theft, fraud, extortion, forgery, and others. Plotting in advance or voorbedachteraad is a crime of murder under Article 340 of the Criminal Code.

Semantic word is a technical term that refers to the study of meaning which in English is meaning. [11] Semantics is a branch of linguistics that will discuss meaning or meaning. [12] Semantics is a field of linguistic studies where the object of research is the meaning of language.[13] Semantic structure is a network of semantic relations between words in the lexical system of a language.[14] The formation of semantic structures is related to the semantic components and these components basically determine the structure of the birth of language. The process of its formation is considered a description of the mental process of speaker-listeners so that the process is called universal. [15] 


\subsection{Morphological process}

The morphological process is the process of changing words in an orderly way or the regular way of changing them with the same tool creates a new meaningful component in the modified word, the resulting new word is polymorphemic. [16] The morphological process is the process of forming words from other units which are their basic form. [17] Morphological process as a way of forming words by connecting morphemes with one another. The morphological process certainly applies to every language. [18]

Affixation is the process of affixing affixes, namely the affixing of affixes to a unit, whether the unit is a single form or a complex form to form words. [19] Affixation is the fusion of affixes (affix) on the basic morpheme. This affixation process has two main functions, namely: 1) flexion, namely affixation which forms alternants of the form which are still the same word, or lexical element; 2) derivation, namely affixation that derives words or other lexical elements from certain words or lexical elements. [20] Affixation is the process of affixing an affix to a basic word or basic form. [21]

Abbreviation is the process of dating one or more parts of the lexeme or combination of lexemes so that a new form has the status of complex words, acronyms or abbreviations, with various abbreviations, namely by decapitation, contraction, acronym, and abbreviations. [22] Abbreviation is the process of calming parts of a lexeme or a combination of lexemes so that they become a short form, but the meaning remains the same as the full form. So, it can be concluded that the abbreviation is the process of dating part or several parts of the lexeme which form new words without changing the meaning. [23]

\subsection{Social Media}

Social media is a medium on the internet that allows users to present themselves and interact, cooperate, share, communicate with other users, and form virtual social bonds. [24] Social media is today a place within which we socialise, not just a means of communication. Prior to social media there were mainly either private conversational media or public broadcasting media. [25] Based on a survey of 2496 students, Miller (2016) found that most of them were using five or six different social media from a young age.

Thomas L. Friedman (2007) in relation to social media calls it as "The world is flat" that the world is getting more flat and everyone can access anything from any source. As for Richard Hunter (2002) calls it "World Without Secrets", that the presence of new media (new media/cybermedia) makes it easy to find and open.

Through status, comments, notes, and various facilities in social media, many people try to show their existence by continuously updating all existing developments. A development that if in the real world it is impossible to convey, so in the world of social media, this development can become public consumption in general. [26]

Social networking sites are the most popular social media. These social media allow members to interact with each other. Interactions that occur are not just text, but also include photos and videos that may attract the attention of other users. All posts (publications) are a real team that allows members to share information as to what is going on. [27] Meanwhile, according to Lometti, Reeves, and Bybee, the use of media by individuals can be seen from three things, namely: the amount of time, media content, and media relations with individuals. [28]

\subsection{Criminal Spreads Fake News (hoax)}

In Article 28 of Indonesia Government Regulation Number 11 of 2008 concerning Electronic Information and Transactions, there are several elements that must be observed in this article, namely: (1) the element of deliberately spreading information, (2) the element of purpose causing a sense of hatred or individual enmity and/or certain community groups, and (3) basic elements of ethnicity, religion, race and intergroup (SARA).

Provisions regarding the spread of fake news or hoaxes that can issue chaos are regulated in two provisions through Law Number 1 of 1946 concerning Criminal Law. Article 14 of the a quo Law states:

1) Barang siapa, dengan menyiarkan berita atau pemberitahuan bohong, dengan sengaja menerbitkan keonaran di kalangan rakyat, dihukum dengan penjara setinggi-tingginya sepuluh tahun;

2) Barang siapa mengeluarkan pemberitahuan yang dapat menerbitkan keonaran dikalangan rakyat, sedangkan dia patut dapat menyangka bahwa berita atau pemberitahuan itu bohong, dihukum dengan penjara setinggi-tingginya tiga tahun.

Provisions regarding the dissemination of hoax news that can cause hatred against a group are regulated in Article 28 paragraph 2 of Indonesia Government Regulation Number 11 of 2008 concerning Electronic Information and Transactions, which reads "Everyone deliberately and without rights spreads information intended to cause individual hatred or enmity and/or certain community groups based on ethnicity, religion, race, and intergroup (SARA)."

Adequate legal umbrella regarding hoax crime is in Article 28 paragraph 1 and 2, Article 27 paragraph 3, Indonesia Government Regulation Number 11 of 2008 
concerning Electronic Information and Transactions as amended by Law No. 19 of 2016, Articles 14 and 15 of Law No. 1 of 1946, Articles 311 and 378 of the Criminal Code, as well as Law No. 40 of 2008 concerning the Elimination of Racial and Ethnic Discrimination are several legal products that can be used to combat the spread of hoaxes.

Hoax is categorized as an act against the law. Currently, acts against the law in cyberspace are a very worrying phenomenon, considering that carding, hacking, fraud, terrorism, hoaxes, have become activities of criminals in cyberspace, this is still in stark contrast to the lack of regulations governing the use of technology information and communication in these various sectors. [29]

Hoax has even become a commodity that is specifically seen by various parties for different interests and can be used by industry for political, religious, religious interests. [30]

In the Indonesia Government Regulation Number 11 of 2008 concerning Electronic Information and Transactions in Article 28 paragraph (1) there are elements of crime, namely: 1) Error: intentionally, 2) Against the law: without rights, 3) Actions: spreading, 4) Object: false and misleading news, 5) The constitutive consequences result in consumer losses in electronic transactions.
The criminal elements in paragraph (2) are: 1) Error: intentionally, 2) Against the law: without rights, 3) Actions: disseminating, 4) Object: information, 5) Purpose: to cause individual hatred or enmity and / or certain community groups.

\section{RESULT AND DISCUSSION}

In the linguistic forensic point of view, there are elements of argument that must be observed in Article 28 of Indonesia Government Regulation Number 11 of 2008 concerning Electronic Information and Transactions. In paragraph (1) it is stated that Everyone who knowingly and without rights spreads false and misleading news that results in consumer losses in Electronic Transactions. There are several elements of meaning or argument that must be observed in paragraph (1), namely: (1) elements of the agent of each person, (2) elements of adverb using deliberately and without rights, (3) elements of the act of spreading, (4) elements of news objects false and misleading, (5) adverb elements resulting in consumer losses, and (6) time adverb elements in Electronic Transactions. The elements of this argument can be described in the table as follows.

Table 1. Elements of Argument in Article 28 paragraph (1)

\begin{tabular}{|l|l|l|l|}
\hline No & \multicolumn{1}{|c|}{ Linguistic form } & Argument & \multicolumn{1}{c|}{ Explanation } \\
\hline 1 & Setiap Orang & Agent & a term regulated in this law. \\
\hline 2 & $\begin{array}{l}\text { dengan sengaja dan } \\
\text { tanpa hak }\end{array}$ & $\begin{array}{l}\text { Adverb of } \\
\text { manner }\end{array}$ & $\begin{array}{l}\text { It is a term in the field of law, not regulated } \\
\text { as a definition or term in this Law. }\end{array}$ \\
\hline 3 & $\begin{array}{l}\text { menyebarkan } \\
\text { Action }\end{array}$ & $\begin{array}{l}\text { General words, are not regulated as a } \\
\text { definition or term limit in this Law. }\end{array}$ \\
\hline 5 & $\begin{array}{l}\text { yerita bohong dan } \text { mengakibatkan } \\
\text { kerugian konsumen }\end{array}$ & $\begin{array}{l}\text { Adverbia of } \\
\text { result }\end{array}$ & $\begin{array}{l}\text { General words, are not regulated as a } \\
\text { definition or term limit in this Law. } \\
\text { definition or term limit in this Law. }\end{array}$ \\
\hline 6 & $\begin{array}{l}\text { dalam Transaksi } \\
\text { Elektronik }\end{array}$ & $\begin{array}{l}\text { Adverbia of } \\
\text { time }\end{array}$ & a term regulated in this law. \\
\hline
\end{tabular}

eventualis). As for the absence of rights in this

The word orang as a subject argument in this paragraph is a term whose definition is an individual, whether an Indonesian citizen, a foreign citizen, or a legal entity. In the Criminal Code the phrase whoever is used is used, while a criminal act outside the Criminal Code is known as everyone. Both of these terms, whether anyone or everyone have the same connotation in seeing mistakes and accountability, that is, directly referring to a person in a biological connotation, as a person (naturalijk persoon).

The word sengaja s as an adverbial argument in this verse is a legal term and includes the following meanings: 1) deliberate intent (opzet als oogmerk), 2) deliberate certainty (opzet met zekerheidsbewustzjin or noodzak elijkheidbewustzijn), and 3) conscious deliberate possibility (voorwaard elijk opzet or dolus paragraph is also a legal term which means not having the authority or not having the power to do something because it has been determined by laws or other regulations. Without rights, it means that they do not have a valid legal basis to carry out the action in question. The basis for the rights itself can be in the form of statutory regulations, agreements, or other legal grounds, or it can also abuse or exceed the authority given.

The verb to spread as an argument for action has the meaning of squandering; broadcast (news, etc.); sowing (seeds, etc.); or handing out; send.

Berita bohong as object arguments mean stories or information about hot events or news that are inconsistent with the real thing (circumstances, etc.). As 
for the verb to pervert it means to lead to the wrong path; lead astray.

The verb mengakibatkan as an adverb argument of effect has the meaning of "to cause or cause a certain event or condition, to bring about an effect." Thus, this verb requires linguistic facts in the form of events or circumstances of loss for consumers. As for the word loss itself has the meaning of 'regarding loss'. Thus, the linguistic facts that are needed to decide the linguistic forensic view that an act occurs must also have linguistic facts, namely that there is an event or certain state regarding loss. Regarding kerugian referred to is from the consumer perspective.

The phrase transaksi elektronik as an adverbial time argument in this paragraph has been defined as a legal act committed using computers, computer networks, and/or other electronic media.

\section{CONCLUSION}

The grammatical category of menyebarkan verbs in the regulation of article 28 paragraph (1) based on their syntactic structure is an active diathesis verb and is marked morphologically by affixation in the form of the prefix $m e N-$. The semantic feature inherent in the verb to propagate is 'deliberately'. The role of the agent in Article 28 paragraph (1) is interpreted as having the role of an instrument "with technological tools" and the scope of the agent who is, and not those who "menulis" because menulis is a different verb. The semantic structure can be described as follows.

\section{$\mathrm{X}$ does something to $\mathrm{Y}$ \\ something happened to $\mathrm{Y}$ because $\mathrm{X}$ wanted it \\ $\mathrm{Y}$ is divided into 'another' \\ $\mathrm{X}$ uses tools (technology) to do this}

The predicate of a verb that has the potential to be criminalized to spread fake news or hoax about COVID19 on social media was found to contain simulfix, which is a combination of two or more affixes, each of which retains its respective meaning and function. Simulfix (meN-kan) undergoes a change in shape which is almost the same as the prefix (meN-) to (mem-kan), (men-kan), (meng-kan), (meny-kan), and (me-kan). The polymorphemic word menyebarkan contains the affix \{meN-kan\}, namely the bound linguistic form which only has a grammatical meaning, which is a direct element of a word, but not a basic form, which has the ability to form new words.

In the predicate verb sentences on social media that have the potential to be criminalized in spreading fake news or hoax about COVID-19, monomorphemic (like mati, ganti, minum, ada, tau, taruh, tewas, minum, cegah, tahu) and polymorphemic (like meninggal, ternyata, menyebabkan, minumlah, dicampur, membunuh, memburu, tercapai, mengatakan, membuat, menciptakan, berdampak, membuat, mengganti, tularkan, terjebak, mengharuskan, meng-autopsi) forms are found.

As for the diathesis, it was found that the news had a predicate of verbs with active and passive diathesis. Based on the mode, it was found that news that had the potential to spread fake news or hoax about COVID-19 had a declarative (like Vietnam tidak ada korban meninggal Covid-19 karena teh dan lemon; Cina dan WHO berbohong tentang Covid-19) and imperatif mode (like Minumlah teh panas, taruh 2 biji obat amoxicilin ke dalam tandon air di rumah).

Based on its origin, the affix that forms a potentially criminal word spreading fake news or hoax about COVID-19 on social media was found to be the original affix originating from Indonesian. Based on its placement, the affix $\{$ meN-kan $\}$ is a combined affix or a combination of affixes, namely a combination of two or more affixes that join the base. The characteristics of the combined affix \{meN-kan $\}$ are: (1) not together to form a new meaning, (2) this combined affix to form a verb type word (action). The combination function of the affix $\{$ me-kan $\}$ in this context is to form a verb with an active diathesis. In the process of word formation, the affix combination \{meN-kan changes form. In terms of meaning, the combination of the affix \{me-kan\} contains the meaning of "making so (causative)". In the context of Article 28 paragraph (1), what is meant is the 'spread of false and misleading news' The causative meaning in this paragraph demands an argument in having a 'target' case that what is distributed is really accepted, known, including the sensing results as seen , read, or be heard. As for the causative meaning formed by the affix combination affix $\{$ meN-kan $\}$ in paragraph (1), thus it can be interpreted that the false and misleading news has been accepted/known /read /heard/ seen by others.

Words that use the verb $\{$ meN-kan $\}$ on social media and have the potential to spread fake news or hoax are: mengatakan, menciptakan, mengharuskan, menyebabkan, menjauhkan, mematikan, mengingatkan, menyelamatkan, melarikan. The words that use the verb $\{\mathrm{meN}-\mathrm{i}\}$ are: menjangkiti, menggerogoti, mengobati. Words that use the verb $\{\mathrm{meN}-\}$ are: meninggal, membunuh, menjadi, memburu, membuat, memegang, meng-autopsi, membeku, memberi, menghadang, menyuruh, mengundang, menghirup, membuat. The words that use the verb \{di-kan\} are: dirapatkan, dilarikan, dilaksanakan, diperhatikan. Words that use the verb $\left\{\mathrm{di}_{-}\right\}$are: diminta, dipakai, dibaca, dipegang, dikubur, dibuat, diambil, dibuka, ditutup. The words that use the verb $\{\mathrm{di}-\mathrm{i}\}$ are: diketahui, ditakut-takuti, ditanggulangi. The words that use the verb \{ter- $\}$ are: ternyata, tertular, terpapar, terbukti. Words that contain the verb \{ber-\} are: berbohong. The words that use verb reduplication are: diada-adakan, ditakut-takuti. 
Meanwhile, the monomorphemic forms that appear are: mati, minum, ada, ganti, tahu, tau, taruh, tewas, minum, cegah.

Information on social media and potentially criminal to spread false news (hoax) about Covid-19 can be classified as: 1) the characteristics of the corona virus: for example virus korona itu tidak alami; corona bukan dari virus tapi dari Bakteri; 2) The source of the corona virus: for example Cina telah membuatnya; 3) Distribution of corona: for example melalui sarung tangan petugas rapid tes, melalui udara; 4) Corona virus barriers: for example merokok, menghirup udara presto; 5) the corona cure: for example menghirup uap panci presto; and 6) the condition of the figures: for example Anies susul trump terpapar covid-19.

The element of intent that is in what is said on social media and has the potential to be criminalized in spreading fake news about Covid-19 can be described as follows.

1) Advise, such as: Petugas Rapid Test Jarang Mengganti Sarung Tangan, Bisa Tularkan Covid-19 dari Pasien Sebelumnya; Menghirup Uap Panci Presto Dapat Mengobati COVID-19.

2) Confirming, as in: Corona Virus adalah BOHONG. bukan dari Virus tapi dari Bakteri. semua ini diketahui oleh negara Itali; Profesor Dr Tasuku Honjo mengatakan bahwa virus korona itu tidak alami. Cina telah membuatnya; Corona itu adanya di China bukan di sini. Di sini Cuma diada-adakan.

3) Reporting, such as: Vietnam Tidak Ada Korban Meninggal Covid-19 Karena Teh dan Lemon; 59 Jemaat Gereja Tewas Minum Dettol demi Cegah Corona; Merokok dapat menghadang virus Corona atau COVID-19 menjangkiti seseorang; Anies Baswedan Terpapar COVID-19 dan Dilarikan ke RS Royal Sunter.

Utilization of the results of this research can be carried out through tasks related to the analysis of language forms that fulfill criminal or civil elements. The task in question is Task 5, which is to find expressions that meet the criminal elements in the digital criminal case statement. In doing step 3. Analyze the expressions or forms of language used and have the potential to fulfill the criminal element in the instructions for the 5th Task, students must be able to find the meaning of each word in: 1) linguistic facts, and 2) legal norms that are alleged to have been violated.

\section{ACKNOWLEDGMENT}

This research was funded by PNBP funds from the Faculty of Language and Arts Universitas Negeri Jakarta in the 2020 budget year.

\section{REFERENCES}

[1] Abdul Wahid dan Mohammad Labib. (2005). Kejahatan Mayantara (Cyber Crime), Jakarta: PT. Refika Aditama, p. 40.

[2] Vibriza Juliswara. Mengembangkan Model Literasi Media yang Berkebhinnekaan dalam Menganalisis Informasi Berita Palsu (Hoax) di Media Sosial. Jurnal Pemikiran Sosiologi Volume 4 No. 2, 2017, p. 162.

[3] Ulya. Post-truth, Hoax, dan Religiustitas di Mediai Sosial. Fikarah Jurnal Ilmu Akidah dan Keagamaan. Volume 6 Nomor 2 Tahun 2018. p. 299.

[4] Srian Kumar, Neil Shah. False Information on Web and Social Media: A Survey. Researchgate Vol. 1, No. 1, Article . Publication date: April 2018. p. 7.

[5] https://inet.detik.com/cyberlife/d-4931925/mafindohoax-soal-corona-sama-berbahaya-dengan-virusnya. accessed in 9 April 2020.

[6] https://aptika.kominfo.go.id/2020/08/hingga-10agustus-kominfo-tangani-1-082-hoaks-covid-19-diberbagai-platform/ accessed in 13 Oktober 2020.

[7] Narila Mutia Nasir, Baequni, Mochamad Iqbal Nurmansyah. Misinformation related to Covid-19 in Indonesia. Jurnal Administrasi Kesehatan Indonesia Vol 8 No 1 Special Issue 2020. p. 56.

[8] George Yule. (1996). Analisis Wacana. Terjemahan Sutikno. Jakarta: Gramedia, p. 3.

[9] Louise Cummings. (2007). Pragmatik Sebuah Perspektif Multidisipliner. Yogyakarta: Pustaka Pelajar. p. 42.

[10] Harimurti Kridalaksana. (2008). Kamus Linguistik. Jakarta: Gramedia. Pustaka Utama. p. 148.

[11] Mansur S. Pateda. (2003). Semantik Leksikal. Jakarta: Rineka Cipta. P. 79.

[12] JWM.Verhaar, JWM. (2006). Asas-Asas Linguistik Umum. Yogyakarta: Gadjah Mada University Press. p. 13.

[13] Abdul Chaer. (2012). Linguistik Umum. Jakarta: Rineka Cipta. p. 52.

[14] John Lyons. (1995). Pengantar Teori Linguistik. Jakarta: Gramedia Pustaka Utama. p. 59.

[15] D.P. Tampubolon, Abubakar, Sitorus, M. (1979). Tipe-Tipe Semantik Verba Bahasa Indonesia Kontemporer. Jakarta: Pusat Pembinaan dan Pengembangan Bahasa. P. 5-6.

[16] Sudaryanto. (1992). Metode Linguistik. Yogyakarta: Gadjah Mada University Press. p. 15. 
[17] M. Ramlan. (1987). Morfologi: Suatu Tinjauan Deskriptif Ilmu Bahasa Indonesia. Yogyakarta: Karyono. p. 51.

[18] Samsuri. (1988). Analisa Bahasa. Jakarta: Erlangga. p. 190.

[19] Ramlan, M. (1987). Morfologi: Suatu Tinjauan Deskriptif Ilmu Bahasa Indonesia. Yogyakarta: Karyono. p. 54.

[20] JWM. Verhaar. (2006). Asas-Asas Linguistik Umum. Yogyakarta: Gadjah Mada University Press. p. 107.

[21] Abdul Chaer. (2012). Linguistik Umum. Jakarta: Rineka Cipta. p. 177.

[22] Harumurti Kridalaksana. (2007). Pembentukan Kata dalam Bahasa Indonesia. Jakarta: Gramedia. p. 162-163.

[23] Abdul Chaer. (1995). Pengantar Semantik Bahasa Indonesia. Jakarta: Rineka Cipta. p. 65.

[24] Rulli Nasrullah. (2015). Media Sosial: Perspektif Komunikasi, Budaya, dan Sosioteknologi. Bandung: Simbiosa Rekatama Media. p. 11.

[25] Daniel Miller et al. (2016). How the World Changed Social Media. London: UCL Press. pp. 3-4.

[26] Errika Dwi Setya Watie. Communications and Social Media. THE MESSENGER, Volume III, Nomor 1, Edisi Juli 2011 74. pp.73-74.

[27] S. Saxena. (2014). "Social Media can be Organized in 6 Clear Categoris". Retrieved From http://www.easymedia.in/ social-media-can-organized6-clear-categories/. accessed in 9 Mei 2020.

[28] Thea Rahmani. ( 2016). Penggunaan Media Sosial Sebagai Penguasaan Dasar-Dasar Fotografi Ponsel. Yogyakarta: Universitas Islam Negeri Sunan Kalijaga Yogyakarta. p. 22.

[29] Siswanto Sunarso. (2009). Hukum Informasi dan Transaksi Elektronik (Studi Kasus; Prita Mulyasari),Jakarta: Rineka Cipta. p. 40.

[30] Rieka Mustika. Communication ethics in the online media in avoiding hoax. Jurnal Diakom | Vol. 1 No. 2, Desember 2018. pp. 43-50. 